\title{
Optimization of Educational Mobile Game Design 'Ayo Wisata ke Riau' based on User's Perspective
}

\author{
Anggy Trisnadoli ${ }^{1}$, Jan Alif Kreshna ${ }^{2}$ \\ Information Technology Department, Politeknik Caltex Riau ${ }^{1,2}$ \\ anggy@pcr.ac.id ${ }^{1}$,janalif@pcr.ac.id ${ }^{2}$
}

\begin{tabular}{l} 
Article Info \\
\hline Article history : \\
Received Nov 4, 2020 \\
Revised Jan 13, 2021 \\
Accepted July 6, 2021 \\
\hline
\end{tabular}

Keywords :

Reengineering

User's Satisfaction

Mobile Game

Educational Game

Tourism

\begin{abstract}
Educational Mobile Game 'Ayo Wisata ke Riau' is a mobile-based educational game application that was developed in 2017 on the Android platform. The quality requirements used in this game development have been adjusted for the available Educational Mobile Games. Even though it went well, there were many complaints from users during the direct implementation survey. This becomes material for re-evaluation, whether the game is ready to be disseminated to the public. Based on this occurence, a gap analysis was carried out to see the feasibility and the need for improvements to the game application that had been built. Based on the results of the gap analysis that has been carried out, it is indicated that there is a need for significant improvements in the areas of performance and user satisfaction. So that in this study, a design reengineering was carried out that was focused on improving the two things that were considered crucial, so that the results of the design and implementation that had been improved could provide better performance and user satisfaction scores than previous developments.
\end{abstract}

Corresponding Author:

Anggy Trisnadoli, Information Technology Department Politeknik Caltex Riau Jl. Umbansari (Patin) No. 1 Rumbai, Pekanbaru, Riau, Indonesia, 28265 Email : anggy@pcr.ac.id

\section{INTRODUCTION}

The development of the educational mobile game "Ayo Wisata ke Riau" has been carried out by Febrianto, et al. [1] on the Android platform and all of its features can run well. Development is carried out based on the need for game quality that is specific to the mobile-based education genre, these needs have been provided in previous research. Based on this research, there were many complaints and suggestions for improvement from respondents when evaluating the first development. So it is deemed necessary to take further stages before the application is actually distributed publicly to the wider community. To get what needs to be considered from previous developments, a Gap Analysis is carried out.

Gap analysis is carried out to see the extent to which game applications that have been developed before have weaknesses or deficiencies that need attention, so that later you can choose which steps to take in the future. Gap analysis is carried out by comparing the evaluation results that have been obtained previously with the ideal / best value indicator of the quality factor for mobile games. Based on the results of the Gap analysis, it is found that the parts that need to be the attention 
of this application are Performance Efficiency and User Satisfaction. This is reinforced by the many complaints regarding the performance of the game that is not good, the size of the master file is very large and takes up a lot of device memory capacity, delays between scenes and so on. Meanwhile, in terms of user satisfaction, the discussion of deficiencies can be seen from the appearance and content that is not updated and less attractive. So that based on the results of this analysis, it is deemed necessary to revise the educational games being developed. One of the software repair concepts that can be used is Software Reengineering.

Software reengineering is a method for analyzing existing software systems and modifying them into new forms [2]. In this study, reengineering was applied that focused on the parts that were crucial to repair. The target is to redesign these parts by collecting the latest user quality requirements, so that the new design can be implemented towards software improvements based on previous developments. The evaluation result of this research is in the form of a prototype developed with the aim of giving good results that reeingeering carried out on the development of the Educational Mobile Game 'Ayo Wisata to Riau' can increase the satisfaction of the educational game product from the user's perspective.

\section{RESEARCH METHODS}

The activities carried out in this study included conducting Gap Analysis, Quality Requirements Engineering for Educational Mobile Games, Data Collection and Design improvement targets.

\subsection{Gap Analysis}

The educational game application 'Ayo Wisata ke Riau' was previously developed by Febrianto, et al in 2017 [1]. This application is the result of the implementation of the need for quality educational mobile games that have been evaluated for tourism in Riau Province.

The result of the development of educational mobile game products is an Android-based application, as in Figure 1 below.

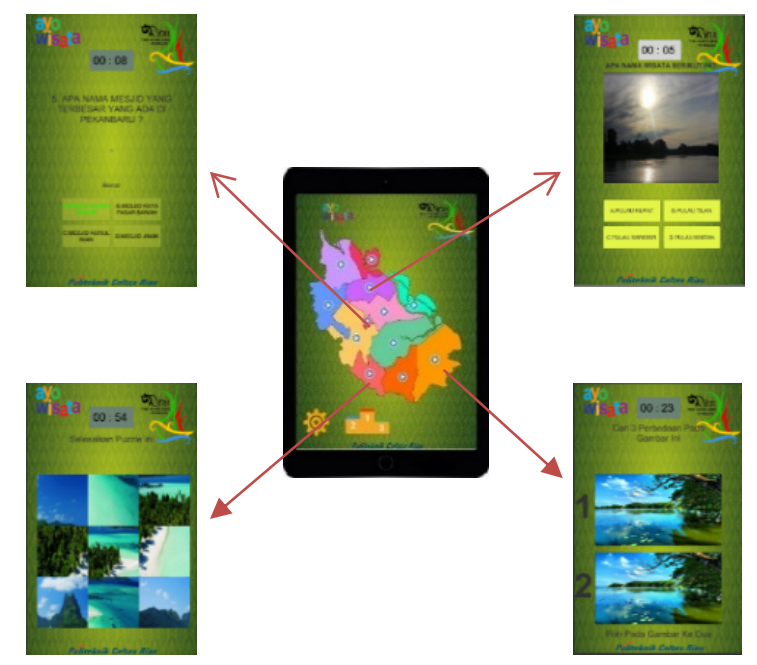

Fig. 1 The old Ayo Wisata ke Riau’ Educational Game Application

In general, educational game applications that have been made have run well after being measured by the Quality Model for Mobile Games [3], but based on the results of the quality and performance satisfaction tests performed on users, they show unsatisfactory results.

After doing GAP Analysis, several deficiencies were found which resulted in the low quality value of the game product [4]. Based on the evaluation, the following in table 1 are the deficiencies found. 


\begin{tabular}{|c|c|c|}
\hline No. & Component & Problems found \\
\hline \multirow[t]{3}{*}{1} & \multirow{3}{*}{$\begin{array}{l}\text { Application's } \\
\text { Performance }\end{array}$} & The master file size is too large \\
\hline & & The installation to the device took a while. \\
\hline & & The delay between scenes is quite long \\
\hline \multirow[t]{5}{*}{2} & \multirow{5}{*}{$\begin{array}{l}\text { User's } \\
\text { Satisfaction }\end{array}$} & Game display is too monotonous. \\
\hline & & The image quality displayed is not very good. \\
\hline & & The content shown is not up to date. \\
\hline & & The trivia given is not very informative. \\
\hline & & The controlling layout is a little confusing. \\
\hline
\end{tabular}

\subsection{Quality Requirements for Mobile Based Educational Games}

Based on the characteristics, which have been described by several researchers [5] [6] [7] [8] [9] [10], an analysis of the characteristics of mobile-based games and applications was carried out for extraction. The activity then provides a list of quality requirements as a basis for building a quality model, as well as determining a quality metric.

Trisnadoli, et al. [11] have engineered quality requirements specifically for tourism education mobile games, with results showing 17 lists of needs including ease of target, ease of use, completeness of features, ease of control, convenience of layout, benefits and effects. education from the game, as well as other needs. The results show that it is necessary to re-implement, so that the prototype improvement is in accordance with the expected quality requirements. After that, return to using the appropriate quality model to determine the value of game quality, so that this value can be used as a reference for the development of good educational mobile games.

\subsection{Data Collection}

To further strengthen the design improvements that will be developed, it is necessary to collect data that aims to review how much interest potential users have to use and provide input in improving existing products [12]. In supporting this research, one of the data collection activities that has been carried out is by conducting Focus Group Discussions from various groups. This is done so that researchers can directly interact with the wider community, especially people in the province of Riau, who are the main target in the use of mobile games that will be developed later [4].

This activity was carried out online with 50 participants and included resource persons who were key in the activity. In addition, data collection is also carried out by conducting an open survey using a questionnaire as a medium to accommodate the opinions of respondents after the new design is developed. Respondents in the evaluation phase were FGD participants who had participated in previous activities, as well as other potential users who were asked for their opinions as supplementary data. This survey activity was attended by around 50 respondents from various circles who live in Riau Province.

\section{RESULT AND DISCUSSION}

This research was conducted qualitatively, so that the design improvements made were sourced from the results of the analysis of potential users' opinions specifically aimed at the game application 'Ayo Wisata ke Riau'.

\subsection{Design Improvements}

Based on the data that has been analyzed from various data collection activities from the previous phase [4], a summary of the results of additional quality requirements can be obtained that can complement the existing quality requirements, as shown in Table 2 below.

Table 2. Recapitulation of optimization results from the user's perspective

\begin{tabular}{ll}
\hline No. & \multicolumn{1}{c}{ Additional Quality Requirements from the FGD Results } \\
\hline 1 & The Tourism Office is ready to help provide info and pictures of tourist objects. \\
\hline 2 & Add a description of the image in the game application. \\
\hline 3 & Images are made more dynamic and interactive.
\end{tabular}

Trisnadoli \& Kreshna, Optimization of Educational Mobile Game Design 'Ayo Wisata ke Riau' based on User's Perspective 


\begin{tabular}{ll}
\hline 4 & The display is adjusted to the user's range. \\
\hline 5 & The image resolution used is more consistent so that it is more diverse. \\
\hline 6 & The history of the tourism object in question can be entered. \\
\hline 7 & Each region has an intro to introduce the area. \\
\hline 8 & The locations and routes to these attractions were also added. \\
\hline 9 & More tourist objects are explored and exposed. \\
\hline 10 & Traditional Malay music can be added as BGM. \\
\hline 11 & The user interface is customized for its Malay coloration and motifs. \\
\hline
\end{tabular}

Table 2 shows that even though previous studies have stated that the need for quality to be prepared is ready, the facts show that when viewed from the user's perspective, there will always be additions and improvements. This happens because from the user's perspective, it is very subjective as to who was the source at the time the research was conducted.

Although it looks subjective, but with a sufficient amount of input and in accordance with the needs of the research, these results can still be used as a benchmark in adjusting and improving the design for mobile game products that become case studies. So that the design results are ready to be implemented.

\subsection{New Prototype Implementation}

The development of a prototype from the latest design that has been improved should not encounter any significant obstacles, if the design is built accordingly, so the results will also be better. The revised design results are then built into several interface images for the prototype which are developed as an optimization of the appearance of the educational mobile game 'Ayo Wisata ke Riau', as shown in Figure 2.

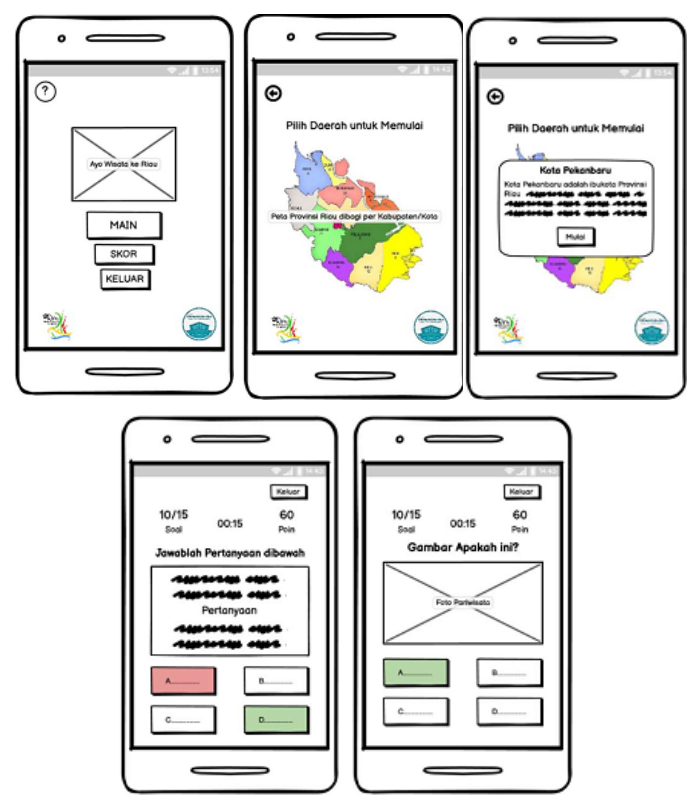

Fig. 2 Interface improvement plan

Furthermore, the design is implemented in the form of a Digital Prototype which has all the functions of a full application that will be officially released, but this prototype application is still prototype but ready for testing needs. The results can be seen in Figure 3 below. 


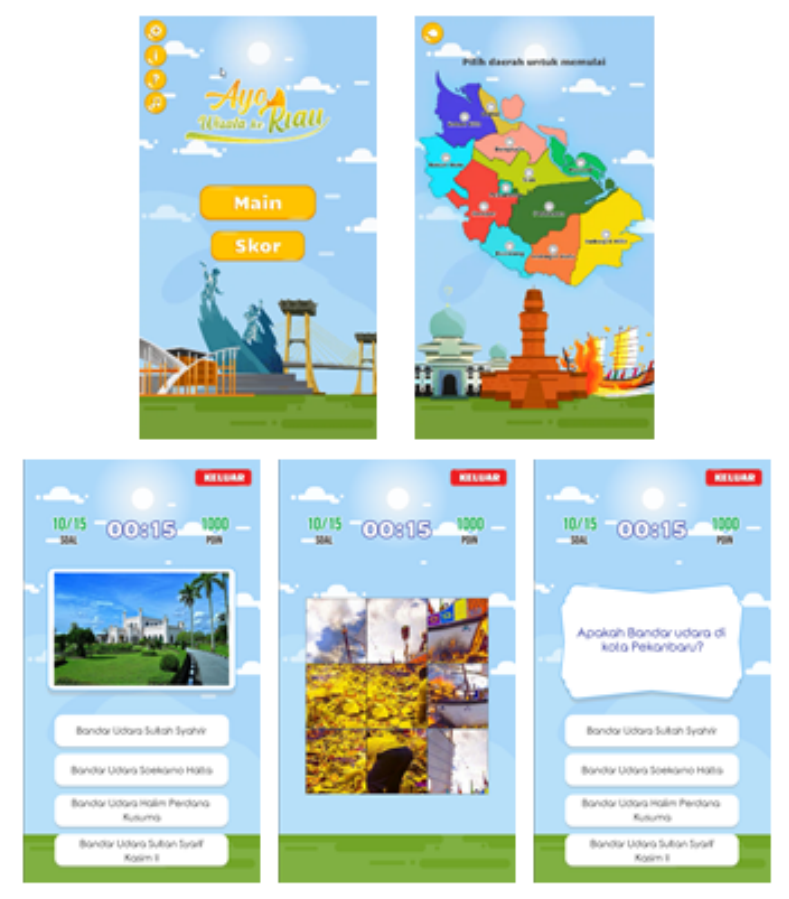

Fig. 3 The new digital prototype of 'Ayo Wisata ke Riau'

The prototype is again tested and evaluated based on the user's perspective, so that later the prototype can be properly implemented in the form of a mobile game software product that is ready to be published.

\subsection{Prototype Evaluation Analysis}

The prototype developed is a medium that is used as a first step in evaluating the optimization of the educational mobile game product design that will be re-engineering. This prototype was built in accordance with the results of the design improvement analysis that had been developed. Furthermore, the evaluation is carried out to get the opinion back from potential users.

The data collection stage for this evaluation was carried out using an online questionnaire that was sent back to the FGD participants who had previously participated, this purpose was to confirm whether the results of the improvements provided were in accordance with what was expected when the process was carried out [13].

The development of the online questionnaire used in this study is based on the Quality Model from Mobile Games [3] especially on the quality factor of user satisfaction. In this model, it has been explained in detail how to collect data and represent data related to user satisfaction based on the quality metrics that have been provided, so that doing data analysis does not require other statistical test tools.

Apart from the FGD participants, other respondents were given the opportunity to give their opinion regarding the prototype, with the aim of adding additional data for potential user opinions based on the user's perspective who later had the opportunity to play the game. Overall, the total number of respondents in this activity was 45 people who came from various circles of society who live in Riau Province.

User opinion data is then processed and presented in the form of the resulting values as in table 3 below.

Table 3. The results of the evaluation of user satisfaction scores

\begin{tabular}{cccccc}
\hline \multirow{2}{*}{ Matrix } & \multirow{2}{*}{ Statement } & \multicolumn{2}{c}{ Before } & \multicolumn{2}{c}{ After } \\
\cline { 2 - 5 } & & Score & Average & Score & Average \\
\hline \multirow{2}{*}{ Satisfaction Scale } & $\mathbf{1}$ & 3,60 & $\mathbf{3 , 6 2}$ & $\frac{3,80}{3,80}$ & \multirow{3}{\mathbf{3}77}{} \\
\cline { 2 - 4 } & $\mathbf{2}$ & 3,53 & & \\
\hline
\end{tabular}

Trisnadoli \& Kreshna, Optimization of Educational Mobile Game Design 'Ayo Wisata ke Riau' based on User's Perspective 


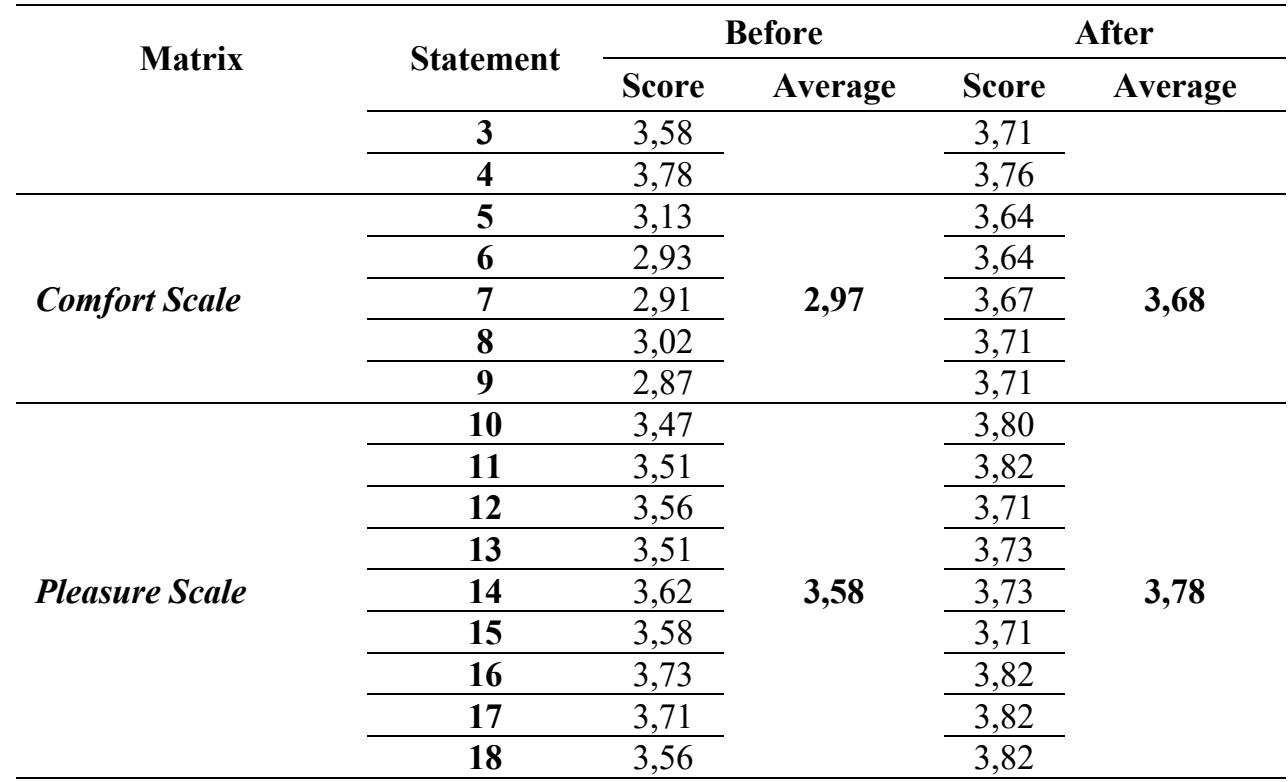

In accordance with the provisions of the quality measurement metric used, based on the scores contained in table 3 previously, each metric is categorized into 4 levels, namely Poor, Fairly Good and Very Good so that the comparison of the values can be seen in Figure 4 below.

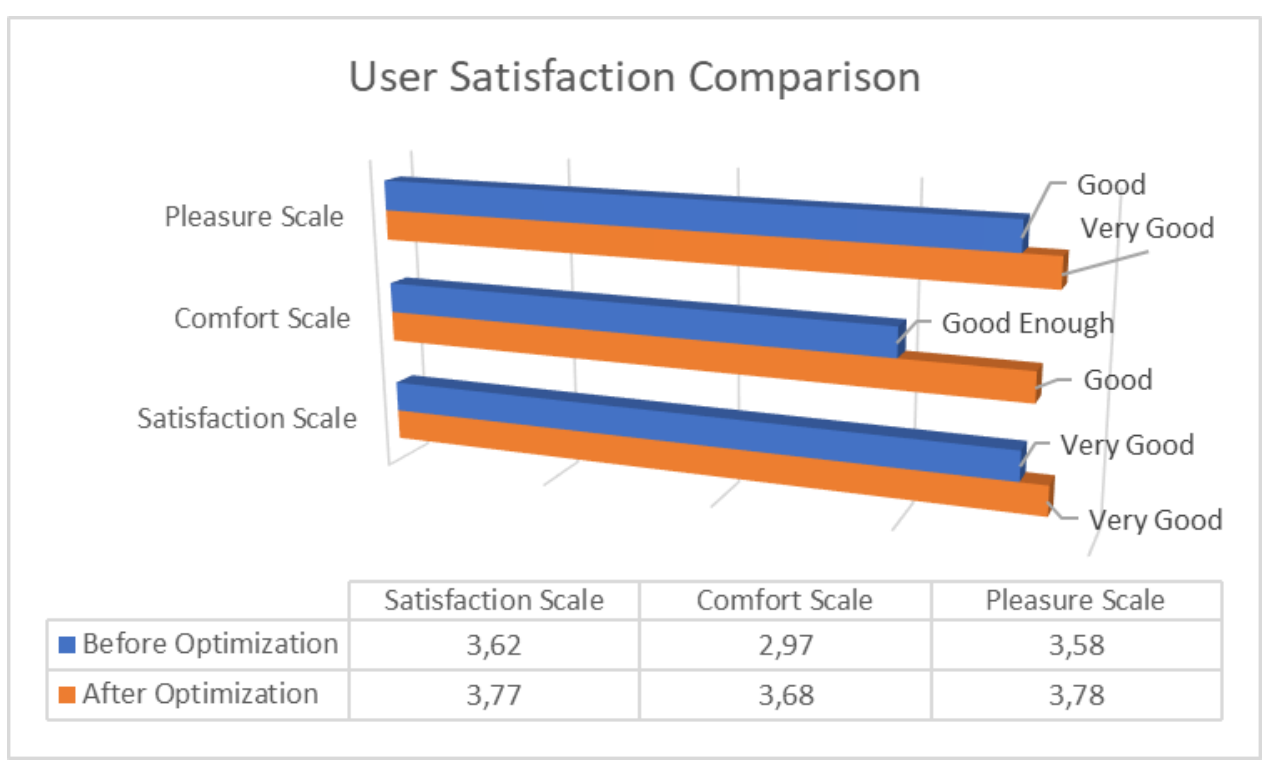

Fig. 4 Evaluation Results of the Prototype 'Ayo Wisata ke Riau'

Based on Figure 4, it can be seen that, in general, respondents have agreed and are satisfied with the developed prototype so that it is ready to be continued in the implementation of educational mobile game software products. Although there is still some user dissatisfaction on the size side. This is due to the habit of users who use mobile phones with a fairly small screen size, so that the display looks denser and the accessibility of the application is a little more disturbed because it can be disturbed by wrong key presses.

\section{CONCLUSION}

The conclusion that can be drawn based on this research is that design optimization can be carried out from the user's perspective. This is evidenced by the increase in user satisfaction results from previous products to new product designs that have been redesigned. 
In future research, a deeper evaluation analysis can be carried out using an appropriate quality model to measure the quality value of a mobile game based on the prototype implementation that has been prepared at this time, so that the quality value can be a reference in proving the optimization of the design results, not only in terms of use, but also in terms of software performance.

\section{AKNOWLEDGEMENT}

In this research, the writer gives thanks to the Politeknik Caltex Riau, which has provided financial support. As well as the Dinas Pariwisata Provinsi Riau and the Riau Province Community who have participated as sources and respondents who support the smooth implementation of this research.

\section{REFERENCES}

[1] E. Febriano, A. Trisnadoli e Y. E. Putra, "Pembangunan Mobile Game Edukasi Kebudayaan dan Pariwisata Provinsi Riau," Jurnal Aksara Komputer Terapan, vol. 6, n 2, 2017.

[2] A. Kumar e B. S. Gill, "Maintenance vs. Reengineering Software Systems," Global Journal of Computer Science and Technology, vol. 11, nº 23, 2011.

[3] A. Trisnadoli, B. Hendradjaya e W. D. Sunindyo, "A Proposal to Quality Model for Mobile Games," em International Conference on Electrical Engineering and Informatics (ICEEI) IEEE, Denpasar, Bali, 2015.

[4] J. A. Kreshna e A. Trisnadoli, "Pengumpulan Kebutuhan Kualitas Dari Pengguna Dalam Rangka Reengineering Aplikasi Permainan Edukasi 'Ayo Wisata ke Riau'," em Seminar Nasional Teknologi Informasi \& Ilmu Komputer (SEMASTER) 2020, Pekanbaru, 2020.

[5] H. Korhonen, "The Explanatory Power of Playability Heuristics," ACM, 2011.

[6] E. J. Jeong e J. Kim., "Definitions, Key Characteristics, and Generations of Mobile Games," monile Computing, 2009.

[7] I. Salmre, Writing Mobile Code Essential Software Engineering for Building Mobile Applications, Encarta: Addison Wesley Professional, 2005.

[8] F. Nayebi, J.-M. Desharnais e A. Abran, "The State Of The Art of Mobile Game Application Usability Evaluation," Ecole de Technologie Supérieure, 2012.

[9] A. Hussain e M. Kutar, "Usability Metric Framework for Mobile Phone Application," em $A C M$, New York, 2008.

[10] A. Trisnadoli, “Analisis Kebutuhan Kualitas Perangkat Lunak untuk Mobile Games," Jurnal Komputer Terapan, vol. 1, n 2, 2015.

[11] A. Trisnadoli, I. Lestari e Y. Fitrisia, "Rekayasa Kebutuhan Kualitas Perangkat Lunak untuk Peningkatan Nilai Kualitas Game Edukasi berbasis Mobile dengan Tema Pariwisata," SATIN - Sains dan Teknologi Informasi, vol. 4, $\mathrm{n}^{\circ}$ 2, 2018.

[12] D. Franke e C. Weise, "Providing a Software Quality Framework for Testing of Mobile Applications," em IEEE International Conference on Software Testing, Verification and Validation, 2011.

[13] A. Ponnada e A. Kannan, "Evaluation of Mobile Games using Playability Heuristics," International Advances in Computing, Communications and Informatics, 2012. 


\section{BIOGRAPHY OF AUTHORS}

Anggy Trisnadoli, obtained an Applied Bachelor's degree in Informatics Engineering,
Politeknik Caltex Riau in 2011, then also received a Master of Engineering degree in Informatics
from the Bandung Institute of Technology in 2015. He currently works as a lecturer at the
Politeknik Caltex Riau, Indonesia since 2012. He currently teaches at Department of
Information Technology. His research interests are Mobile Applications, Games, 3D Animation
and Software Engineering.

